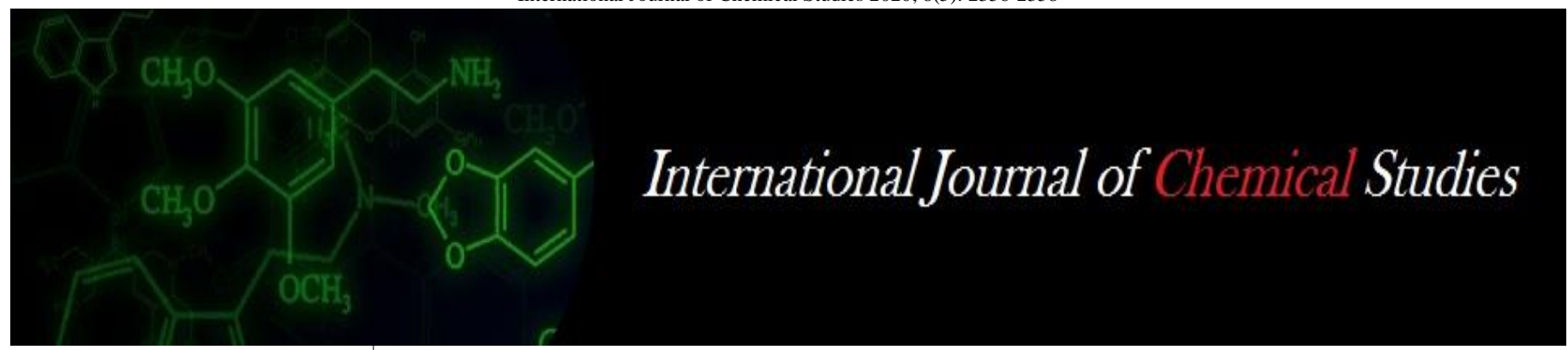

P-ISSN: 2349-8528

E-ISSN: 2321-4902

www.chemijournal.com

IJCS 2020; 8(5): 2356-2358

(C) 2020 IJCS

Received: 25-07-2020

Accepted: 29-08-2020

\section{PS Tiwari}

Krishi Vighyan Kendra,

Hastinapur (S.V.P.U.A. \& T.)

Meerut, Uttar Pradesh, India

Rakesh Tiwari

Krishi Vighyan Kendra,

Hastinapur (S.V.P.U.A. \& T.)

Meerut, Uttar Pradesh, India

Omvir Singh

Krishi Vighyan Kendra,

Hastinapur (S.V.P.U.A. \& T.)

Meerut, Uttar Pradesh, India

Corresponding Author:

PS Tiwari

Krishi Vighyan Kendra,

Hastinapur (S.V.P.U.A. \& T.)

Meerut, Uttar Pradesh, India

\section{Assessment of productivity and soil fertility of Meerut in irrigated Agro-ecosystem of western Uttar Pradesh}

\author{
PS Tiwari, Rakesh Tiwari and Omvir Singh
}

DOI: $\underline{\text { https://doi.org/10.22271/chemi.2020.v8.i5af.10673 }}$

\begin{abstract}
The population of India is likely to reach by 1.4 billion in 2025 as urban. With per capita land availability ha and net availability of cereals and pulses $<450 \mathrm{~g} \mathrm{~d}^{-1}$, India is facing challenge in coping up with the national food security and environmental sustainability. Western Uttar Pradesh registered a high agricultural growth during the second wave of 'Green Revolution' in 1980'. However, rapid urbanization and developmental processes are increasingly in conflict with other forms of land use, especially agriculture. The study addresses the productivity trends and soil fertility status of Meerut district of western Uttar Pradesh. The Soil fertility has direct implication on the agriculture production scenario of the region. Soil Samples from 10 villages covering 5 Block were collected during the period of 2018-19. Result showed that the soil organic carbon content was $0.55 \%$ which is lower than the required amount $0.89 \%$ of OCM in the soil. Available minimum nitrogen Phosphorus and Potash were found $184 \mathrm{~kg} / \mathrm{ha}$, $11.2 \mathrm{~kg} / \mathrm{ha}$ and as $91.8 \mathrm{~kg} / \mathrm{ha}$ which are medium. The nitrogen plays the important role for the better yield and growth of crop and good yield (Tandon, H.L.S. 2017) soil nutrient balance sheet in India importance status issues and concerns. Better crop India a crossed 2016, also supported. In (table-1). The micronutrients Manganese Zink, Iron and Copper were also tested for above blocks of the district (Table 2). The average minimum, maximum and average of minimum and maximum Manganese, Zink, Iron and Copper were found as $2.80,0.66 \mathrm{ppm} 3.42$ and $.32 \mathrm{ppm}$ respectively which are less than the required amont. It was observed that the micronutrients are low to medium amounts presents in the soil of the Meerut district therefore recommended to apply these nutrients from outside to obtain maximum productivity. It is argued that augmenting the production through assessment of biophysical potential of district can ensure food security and sustainability of the system.
\end{abstract}

Keywords: Soil health card, productivity, grid, soil fertility

\section{Introduction}

The Soil is the most important natural resource which is scientifically utilized for improving the productivity and economic condition of the farmers of western UP, soil fertility has district effect on the agricultural production scenario of the region. Parameters help to relate of the nutrient input rates with the crop demand and thus conserve the resources. The use of fertilizers without considering the soil fertility status and crop requirement may adversely affect the soil and crops. The imbalance and inadequate with low efficiency of their inputs, response (production), and efficiency of chemical fertility nutrients has declined tremendously under intensive agriculture in recent years.Meerut district lacks in comprehensive information about Soil fertility status. Study. to assess the fertility status and Meerut district through geographic information system (GIS) can help in making nutrient management decisions (Santhi, R., Selvakumari, G.and Rani Perumal 2010) ${ }^{[3]}$. Soil test based fertility recommendations under integrated plant nutrition. System for rice- -pulse cropping sequence. The integrate variability of soil fertility parameters namely soil Organic Carbon (SOC), Nitrogen $\left(\mathrm{N}_{2}\right)$ Phosphorus $\left(\mathrm{P}_{2} \mathrm{O}_{5}\right)$, Potassium $\left(\mathrm{K}_{2} \mathrm{O}\right)$ Iron $(\mathrm{Fe})$ Management $(\mathrm{Mn})$, Zinc $(\mathrm{Zn})$, and Copper $(\mathrm{Cu})$. It was tested at Krishi Vigyan Kendra, Meerut in soil Testing Laboratory and by developing a unique methodology to identify multi nutrient deficient area using by GIS tools, Sellamuthu, K. M., Santhi R., Maragatham, S. and Dey. P. $2015^{\text {[4] }}$. Balanced fertility prescription for glory lily through inductive- cum targeted yield model on an Alfisol. 


\section{Materials and Methods}

Meerut district is situated in the western part of Uttar Pradesh and comes under Western Plain Zone. Present study five blocks Meerut, Rajpura, Mawana, Hastinapur and Parishitgarh of Meerut District were selected with two villages from each blocks. First of all, collected the revenue map of all above villages form revenue department and 432 Grid were demarcated with the support of people's participation of related villages Pradhan. The average area of a grid was 3 to 4 hectares, depends on the irrigation facilities of those groups and 432 grids covered the 5 blocks after that one sample from each grids group were collected and tested.

\section{Results \& Discussions}

The study revealed that the available average carbon percentage of all place of district Meerut is found minimum and also the minimum and maximum was observed less as required for quality production. The soil organic carbon not only stores nutrients in the soil but it is also a direct source of nutrients. The most fertile soil contains high amounts of organic matter. It is important to maintain soil organic matter (OSM) by adding fresh amount of animal and plant residue as it performs many functions. Available minimum nitrogen 184 $\mathrm{kg} / \mathrm{ha}$ and maximum $334 \mathrm{~kg} / \mathrm{ha}$, the average nitrogen of the district is $260 \mathrm{~kg}$., which was found at par. The nitrogen plays the important role for the vigorous growth of crop and good yield (Tandon, H.L.S. 2017) ${ }^{[6]}$ soil nutrient balance sheet in India importance status issues and concerns. Better crop India a crossed 2016, also supported. In (table-1), 11.12 minimum available phosphorus in the District is $11.2 \mathrm{~kg} / \mathrm{ha}$ and maximum was found as $14.8 \mathrm{~kg} / \mathrm{ha}$ and $\mathrm{P}_{2} \mathrm{O}_{5}$ is less as required level when $\mathrm{P}_{2} \mathrm{O}_{5}$ plays the key role in the pulses production and potassium $\mathrm{k}_{2} \mathrm{O}$ is minimum as $91.8 \mathrm{~kg} / \mathrm{ha}$ which was also very less as compared to the minimum needed where as average available was $155.4 \mathrm{~kg} / \mathrm{ha}$ while needed is also more as $260 \mathrm{~kg} / \mathrm{ha}$. Therefore it is advisable for increase the OCM, $\mathrm{P}_{2} \mathrm{O}_{5}$ and $\mathrm{k}_{2} \mathrm{O}$ in the district to enhance the productivity. Potassium plays role on healthy grain production and disease resistant in the crop. On the soil analysis based SOC, $\mathrm{P}_{2} \mathrm{O}_{5}$ and $\mathrm{k}_{2} \mathrm{O}$ all are less in comparison to the required quantity Kumar, M.V., Saliha, B.B. Kannan, P. and Mehendran, P.P., (2015) [1] delineation and geographic information system (GIS) mapping of soil nutrient status. To increase the quality production and sustainable agriculture, it is recommended to apply the recommended dose as per need as mentioned on soil health cards. Singh, V.V., Manoj Parihar., Singh, S.K., Sharma, P.K., Dey, P. $2015^{[5]}$. Soil test based fertilizer prescription under integrated plant nutrient management system for maize in an Incept sol of Varanasi.

Table 1: Soil Analysis

\begin{tabular}{|c|c|c|c|c|c|c|c|c|c|c|c|c|c|c|}
\hline \multirow{2}{*}{ S. No. } & \multirow{2}{*}{$\begin{array}{c}\text { Name of } \\
\text { Blocks }\end{array}$} & \multirow{2}{*}{ Village } & \multicolumn{3}{|c|}{ SOC (\%) } & \multicolumn{3}{|c|}{$\mathrm{N}(\mathrm{Kg} / \mathrm{ha})$} & \multicolumn{4}{|c|}{$\mathrm{P}_{2} \mathrm{O}_{5}(\mathrm{Kg} / \mathrm{ha})$} & \multicolumn{2}{|c|}{$\mathrm{K}_{2} \mathrm{O}(\mathrm{Kg} / \mathrm{ha})$} \\
\hline & & & Min. & Max. & Ave. & Min. & Max. & Ave. & Min. & Max. & Ave. & Min. & Max. & Ave. \\
\hline \multirow[t]{3}{*}{1.} & Meerut & 1. & .40 & .63 & .51 & 187 & 338 & 263 & 12 & 14 & 13 & 90 & 214 & 152 \\
\hline & & 2 & .51 & .75 & .63 & 177 & 324 & 251 & 10 & 15 & 13 & 87 & 206 & 147 \\
\hline & & Av. & .46 & .69 & .57 & 182 & 331 & 257 & 11 & 15 & 13 & 89 & 210 & 150 \\
\hline \multirow[t]{3}{*}{2.} & Rajpura & 1. & .37 & .72 & .55 & 172 & 342 & 257 & 10 & 14 & 12 & 93 & 217 & 155 \\
\hline & & 2 & .36 & .53 & .41 & 188 & 340 & 264 & 8 & 15 & 12 & 96 & 240 & 168 \\
\hline & & Av. & .37 & .63 & .48 & 180 & 341 & 261 & 9 & 15 & 12 & 95 & 229 & 162 \\
\hline \multirow[t]{3}{*}{3.} & Mawana & 1. & .38 & .67 & .53 & 186 & 340 & 263 & 11 & 15 & 13 & 90 & 220 & 155 \\
\hline & & 2 & .52 & .77 & .65 & 178 & 322 & 250 & 10 & 16 & 13 & 95 & 207 & 151 \\
\hline & & Av. & .45 & .72 & .59 & 182 & 331 & 257 & 11 & 16 & 14 & 93 & 214 & 153 \\
\hline \multirow[t]{3}{*}{4.} & Hastinapur & 1. & .44 & .65 & 55 & 185 & 328 & 257 & 15 & 14 & 15 & 89 & 208 & 149 \\
\hline & & 2 & .37 & .66 & .52 & 187 & 340 & 264 & 9 & 10 & 10 & 93 & 216 & 155 \\
\hline & & Av. & .41 & .66 & .54 & 186 & 334 & 261 & 12 & 12 & 12 & 91 & 212 & 152 \\
\hline \multirow[t]{3}{*}{5.} & Parishitgarh & 1. & .44 & .73 & .59 & 185 & 320 & 253 & 11 & 17 & 14 & 87 & 229 & 158 \\
\hline & & 2 & .35 & .74 & 55 & 192 & 345 & 269 & 14 & 15 & 15 & 98 & 230 & 161 \\
\hline & & Av. & .40 & .74 & .57 & 189 & 333 & 261 & 13 & 16 & 15 & 91 & 230 & 160 \\
\hline \multicolumn{3}{|c|}{ District Availability } & .42 & .69 & .55 & 184 & 334 & 260 & 11.2 & 14.8 & 13.3 & 91.8 & 219 & 155.4 \\
\hline \multicolumn{3}{|c|}{ Availability Needed } & .62 & 1.30 & 0.89 & 192 & 345 & 267 & 17.9 & 28.0 & 21.7 & 225 & 282 & 260 \\
\hline
\end{tabular}

Table 2: Soil Analysis

\begin{tabular}{|c|c|c|c|c|c|c|c|c|c|c|c|c|c|c|}
\hline \multirow{2}{*}{ S. No. } & \multirow{2}{*}{ Name of Blocks } & \multirow{2}{*}{ Village } & \multicolumn{3}{|c|}{ Manganese (Mn) (ppm) } & \multicolumn{3}{|c|}{$\operatorname{Zink}\left(\mathrm{ZnSO}_{4}\right)(\mathrm{ppm})$} & \multicolumn{3}{|c|}{$\operatorname{Iron}(\mathbf{F e})(\mathbf{p p m})$} & \multicolumn{3}{|c|}{ Copper(Cu) (ppm) } \\
\hline & & & Min. & Max. & Ave. & Min. & Min. & Max. & Ave. & Min. & Min. & Max. & Ave. & Min. \\
\hline \multirow[t]{3}{*}{1.} & Meeruit & 1. & 1.85 & 2.80 & 2.33 & 1.15 & .096 & 1.10 & 3.70 & 4.70 & 4.20 & .40 & .38 & .39 \\
\hline & & 2 & 2.95 & 2.60 & 2.78 & 1.20 & .94 & 1.07 & 2.90 & 3.90 & 3.40 & .55 & .58 & .56 \\
\hline & & Av. & 2.40 & 2.70 & 2.56 & 1.18 & .95 & 1.09 & 2.30 & 3.80 & 3.80 & .49 & .48 & .47 \\
\hline \multirow[t]{3}{*}{2.} & Rajpura & 1. & 2.70 & 3.20 & 2.95 & .82 & 1.10 & 0.96 & 4.50 & 6.40 & 5.45 & .12 & .19 & .16 \\
\hline & & 2 & 3.10 & 3.40 & 3.25 & .75 & 1.05 & 0.90 & 3.30 & 4.60 & 3.95 & .18 & .22 & .20 \\
\hline & & Av. & 2.9 & 3.30 & 3.10 & .79 & 1.08 & 0.93 & 3.90 & 5.50 & 4.70 & .15 & .21 & .18 \\
\hline \multirow[t]{3}{*}{3.} & Mawana & 1. & 1.55 & 2.55 & 2.05 & .35 & .45 & .41 & 4.60 & 3.30 & 3.95 & .35 & .40 & .38 \\
\hline & & 2 & 1.60 & 2.80 & 2.20 & .45 & .52 & 49 & 3.15 & 4.90 & 4.03 & .45 & .48 & .47 \\
\hline & & Av. & 1.58 & 2.68 & 2.13 & .40 & .49 & .45 & 3.88 & 4.10 & 3.99 & .40 & .44 & .43 \\
\hline \multirow[t]{3}{*}{4.} & Hastinapur & 1. & 1.90 & 3.10 & 2.50 & .62 & .84 & .73 & 3.80 & 4.80 & 4.3 & .38 & .45 & .42 \\
\hline & & 2 & 2.10 & 3.75 & 2.93 & .65 & .91 & .78 & 4.20 & 5.80 & 5.0 & .42 & .52 & .47 \\
\hline & & Av. & 2.0 & 3.43 & 2.72 & .62 & .88 & .76 & 4.0 & 5.3 & 4.65 & .40 & .49 & .45 \\
\hline \multirow[t]{3}{*}{5.} & Parishitgarh & 1. & 1.35 & 1.95 & 1.65 & .32 & .59 & .46 & 3.78 & 4.79 & 4.29 & .15 & .19 & .17 \\
\hline & & 2 & 1.65 & 3.40 & 2.53 & .25 & .47 & .36 & 2.26 & 5.70 & 3.98 & .12 & .16 & .14 \\
\hline & & Av. & 1.50 & 2.68 & 2.09 & .29 & .53 & .41 & 3.02 & 5.25 & 4.14 & .14 & .18 & .16 \\
\hline \multicolumn{3}{|c|}{ District Availability } & 2.08 & 2.96 & 2.52 & .66 & .79 & .73 & 3.42 & 4.79 & 3.59 & .32 & .36 & .34 \\
\hline \multicolumn{3}{|c|}{ Availability Needed } & 2.10 & 3.88 & 2.90 & .45 & 1.15 & 0.80 & 4.0 & 7.79 & 6.0 & .26 & .42 & .29 \\
\hline
\end{tabular}


The micronutrients Manganese Zink, Iron and Copper were also tested for above blocks of the district (Table 2). The average minimum, maximum and average of minimum and maximum Manganese were found as 2.80, 2.96 and 2,52 ppm which are less than required Manganese of the district. Similarly the minimum available Zink was found higher as $0.66 \mathrm{ppm}$ whereas the average Zink was lesser than required $(0.80 \mathrm{ppm})$. The average minimum, maximum and average of minimum and maximum Iron were found as 3.42, 4.79 and $3.59 \mathrm{ppm}$ respectively which are lower than required. Likewise the average minimum, maximum and average of minimum and maximum Copper were found as $.32, .36$ and $.34 \mathrm{ppm}$ respectively which are lesser than average of the district and also the required quantity. It was observed that the micronutrients are low to medium amounts presents in the soil of the Meerut district therefore recomonded to apply these nutrients from outside to obtain maximum productivity.

\section{Conclusion}

Studies on agricultural soil of District Meerut UP for enhancing productivity, the study was conducted in Meerut district during 2017-18. pm selected 10 villages covering four blocks of district Meerut soil samples were collected by utilizing GIS with grid system and 432 soil samples collected, based on one sample from one grid and tested in soil testing laboratories of KVK Meerut delineation and geographic information system (GIS) mapping of soil nutrient status. Studies revealed that the $\mathrm{SOC}, \mathrm{N}_{2}, \mathrm{P}_{2} \mathrm{O}_{5} \mathrm{~K}_{2} \mathrm{O}$ micronutrient except copper, Manganese, Zinc \& Iron are below than the required label Kriging approach for estimating deficient micronutrients in the soil and enhancing the productivity, the integrated nutrient management is required as per need of the soil.

\section{References}

1. Kumar MV, Saliha BB, Kannan P, Mehendran PP. Delineation ad geographic information system (GIS) mapping of soil nutrient status of sugarcane growing tracts of Theni district, Tamil Nadu. Afr. L. Agric. Res. 2015; 10(33):3281-3291. doi;10.5897/AJAR2013.7251.

2. Shukla G, Mishra GC, Singh SK. Kriging approach for estimating deficient micronutrients in the soil; a case study. Int. J Agric. Environ. Biotechnol. 2015; 8(20):309314. doi: 10.5958/2230-732X.2015.00038.8.

3. Santhi R, Selvakumari G, Rani Perumal. Soil test based fertilizer recommendations under integrated plant nutrition system for rice-rice-pulse cropping sequence. J Indian Soc. Soil Sci. 2010; 47:288-294.

4. Sellamuthu KM, Santhi R, Maragatham S, Dey P. Balanced fertilizer prescription for alory lily through inductivecum- targeted yield model on an Alfisol. Res. Crops. 2015; 16(3):555-561.

5. Singh VV, Manoj Parihar, Singh SK, Sharma PK, Dey P. Soil test based fertilizer prescriptions undr integrate plant nutrient management system for maize in an Inceptisol of Varanasi. J Indian Soc. Soil Sci. 2015; 63:83.

6. Tandon HLS. Soil nutrient balance sheets in India: importance, status, issues and concerns, Better cropsIndia, 2016-20117. 